\title{
Study of the problems of technological integration in the manufacturing industry in Russia
}

\author{
Alexander Miller \\ Dostoevsky Omsk State University, Omsk, Russia \\ Maxim Miller \\ Dostoevsky Omsk State University, Omsk, Russia
}

\begin{abstract}
The strategy of scientific and technological development of the Russian Federation defines the priority areas that are believed to become a foundation for innovative development of the domestic market of products/services and will contribute to the transition to environmentally friendly and resource-saving energy, increase the efficiency of production and deep processing of hydrocarbons. In the context of global competition, emphasis is placed on the creation of institutional, financial and legislative mechanisms to ensure the harmonization of scientific, technological, innovation, industrial, economic and social policies.

The need to promote technological resources of industrial manufacturing enterprises determined the relevance of research of the technological integration process, as these enterprises are the key to the economic growth of the country and are in a dire need of a technological breakthrough.

The aim of the article is to study the problems of formation and development of technological integration of manufacturing enterprises in the Russian Federation in the context of priority scientific and technological development of the Russian economy.

The article uses a wide range of general scientific methods: description, generalization and abstraction, construction of concepts, argumentation, and comparison. The main methodological approaches used in the article are: system and process approaches that find their refraction in the scientific and practical material of the general theory of systems, organization theory, as well as technical and technological approach.

A fundamental change in the situation in the manufacturing industries entails the need to diversify the refining sector, which consists in upgrading the production capacity of high-quality semi-finished products for the petrochemical industry. World experience shows that the synergetic effect of the integration of oil refining and petrochemicals provides savings of up to hundreds of millions of dollars a year, and the main part of successful integration projects, located in the Persian Gulf countries, implements a strategy for the production of high-quality raw materials and petrochemical products.

When solving the problems of transition to deep resource-saving technologies in the manufacturing industry, it becomes obvious that it is necessary to develop and implement special management technologies that will form the basis of the strategy of the technological revolution of the domestic industrial complex. According to the laws of technologization, this occurs within the framework of the formation of the sixth technological structure in the world economic system, characterized by the development of intelligent technologies such as "smart plant", as well as the living design of business processes. In this regard, technological integration, as a direction of system technologization, should be a scientifically based concept, which includes a set of mechanisms, tools and methods for practical implementation in the industrial enterprises of the Russian economy.
\end{abstract}

\section{Keywords}

Technological integration, manufacturing industry, strategy, innovation, high-tech products, added value. 


\section{Introduction}

A comprehensive view of the technological integration problem in the manufacturing industry of Russia in terms of innovative transformation of strategic management.

At the industrial enterprises of the manufacturing industry, the need for a complex of organizational, technical, financial and economic studies aimed at identifying the problematic aspects of technological integration, and the transition to a new round of technologizationis actualized.

According to the information of the Ministry of Energy of the Russian Federation, modernization of oil refineries and introduction of new capacities of secondary processes are implemented mainly by enterprises of the group of vertically integrated oil companies. Statistics of the last ten years show that the growth of oil refining is accompanied by an increase in the depth of processing only in enterprises that are part of the integrated economic structures, which indicates the most effective way to promote new technologies within the framework of sustainable links along the value chain. The prerequisites for the accelerated pace of technological integration arose both within the industrial giants and from the destabilization of external factors of functioning in the conditions of failures of agreements on the supply of technological equipment by Western partners. Despite the deterioration of the business climate, the development of the industry continues, the process of technology development involves domestic research and production laboratories, specialized research structures, members of cluster associations (Druzhinin \& Dong, 2018).

Scientific research expenditures, which are related to the costs of creating new knowledge and are classified by scientists as dynamic resources, together with the diversification of skills and competencies, are gradually increasing (Mitea, 2018).However, practice shows that the volume of capital injections into the development of scientific and technological potential of industrial manufacturing enterprises is insufficient. The forecasted efficiency of investment investments was not always achieved by the results of production modernization programs, which determines the importance of the development and implementation of special methods of monitoring costs in the development of fixed capital (Popescu, et al., 2018). The strategy of effective development of investments for the purpose of transition to deeper technological processes is designed to ensure the competitiveness of Russian industry in the world economy.

From the point of scientific significance, the study of technological integration in the manufacturing industries of the Russian Federation will complement the existing approaches to scientific and technological policy at the enterprises of oil refining and petrochemical industries and will supplement the theory of organization with methodological provisions that reveal the essence and content of the conditions and factors of the process of technological integration. This will provide a scientific basis for the methodology of formation of the strategy of scientific and technological development of economic entities in related industries.

\section{Methodology}

\section{Scientific background to the study of technological integration.}

The study of technological integration is inextricably linked with the development of ideas of scientists and economists about the functioning of economic entities with the use of stable and short-term relationships. The gradual unification of the parts and the whole entails the emergence of a system of links between the elements, as a result of which the individual parts lose some of their original identification qualities, acquiring new properties. The main ideas of the development of integration processes in economic systems can be divided into three approaches.

First approach. Its supporters are scientists Gerasina Y., Ilyin M., Machula I., Razmanova S., Khusainov B. They believe that integration at the level of economic structures, in particular the integration of technologies has signs of the formation of the industrial policy of the state, to a greater extent, this applies to economic entities. In particular, Gerasina Y. puts forward indisputable postulates about the role of economic structures in creating favorable opportunities for inter-sectoral cooperation of social work, focusing on the fact that the association of enterprises allows them to carry out large-scale and effective scientific projects, thereby contributing to a global transformation of society from an industrial stage to an information (Gerasina, 2016).The attention of researchers is focused on the search for mechanisms of sustainable industrial growth (Kovacs, 2018). It is established that in the conditions of economic crisis measures of the 
state support directed on joint work with the integrated complexes play essential importance. This dependence has become a characteristic feature of the production, technological and marketing processes of large companies in developing countries, including transnational corporations of China, Brazil, India, Malaysia, whose experience is especially important in connection with the expansion of the geography of Russian industrial associations in the Eastern direction $(\mathrm{Wu}$, Harrigan, Ang, \& $\mathrm{Wu}, 2019)$. According to scientists, the main role in the formation of effective industrial policy is played by technology, involving innovative systems at the state level in a single chain through global transnational corporations (Oughton, et al., 2018).Indeed, integrated economic structures are able to combine the components of the country's national wealth in the form of human capital, fixed assets, minerals, and high-tech intellectual resources (Hardingham, Vrbka, Kliestik, \& Kliestikova, 2018). At the same time, production structures closely interact with the financial sector, government agencies, participate in the infrastructure construction of regions, they can act as "customers" of personnel with pre-demanded competencies in supporting educational institutions, be the initiators and executors of innovative projects (Grossman, 2018). The breadth and purpose of relationships, as well as their maintenance in society, form the basis for the development of industrial companies of a new type.

Second approach. Representatives of the second approach Arutyunova D., Gomtsyan S., Ivanov Yu., Milner B., Boschma R., Hartog M., Dahmen A. consider technological integration as a way to regulate the production activity of complex economic structures. A wide range of studies is reduced to the fact that the integration of technologies is a part of the integration strategy of economic entities.German researcher Dahmen A. focuses on the integration process from the perspective of mechanisms of complex systems management, defining the relationship between development strategy and business reorganization (including through mergers and acquisitions, M\&A) as key factors. If we take into account the cases when the reorganization is aimed at the future growth of the company, such development necessarily affects the increase in production capacity on the basis of new technologies (Neary, et al., 2018). Consequently, the individual strategy of economic structures affects the disclosure of the production potential of the entire industrial complex and increases its capitalization.

Scientists have found that integration associations occur in cycles or waves. For example, so-called "endogenous waves" in vertically adjacent industries combine the advantages of vertical and horizontal mergers. Life cycles of industrial enterprises fit into the overall economic cycles and are being changed under their influence (Yao, \& Zhou, 2015). In this regard, certain dependence can be applied to the development of technological integration, when the sphere of potential changes is in constant motion, and along with technological resources, business processes, property complex, capital, organizational and legal form of activity, management system and structure, strategy and management tactics are subjects to change (Vochozka, et al., 2018).

Third approach. Adherents of the third approach Vishnevsky, Batkhin, Valitov, Klepikov and Proskuryakova (Proskuryakova, 2017) believe that technological integration, as the integration of the company's resources, is provided by the synergetic effect of the combined economic structures.Among the "private synergies" of technological integration are the effects of consolidation, such as savings in administrative costs due to the growth of the scope of activities and the centralization of special services, the combination of complementary resources, including technologies, as well as the increase in the market niche of the corporation and the diversification of assets.By combining complementary technologies, additional value is created, as well as value added, which refers to the amount of resources that is generated directly in the enterprise and can be expressed in terms of the total amount of wages, profits, financial costs of interest on borrowed credit resources, as well as depreciation, when it comes to renewable value through the reuse of production capacity.

The modern approaches of Russian specialists Vishnevsky, Karasev, and German researcher Meisner, are based on foresight studies and road mapping of the production process (Vishnevskiy, Karasev, Meissner, Razheva, \& Klubova, 2017). The methods of building complex integrated systems directly link the integration process from the development of the strategy at the entrance to the control of information on integrated business units at the output (Proskuryakova, 2017).

Technological integration can expand the socalled "strategic economic zone" (abbreviation 
SEZ), i.e. the segment of the market of high-tech products, which is of interest to end users. This zone can be increased by "penetration of the company into new product areas associated to varying degrees with the produced products". Preventive measures should come from a structural unit called the "strategic economic center" (abbreviated as the SEC)."The concept of SEZ and SEC" is of particular importance in modern conditions, when the requirements for standardization of products and services in order to develop promising markets have become stricter. In this case, we can use the idea of "structural functionalism" of D. E. Durkheim, T. Parsons, N. Smelser, describing the economy as a social system that seeks to integrate its elements through the performance of functions: adaptation to the external environment, achievement of goals, internal coordination and integration, preservation of reference points. The application of these functions to modern economic structures is considered by the author as an opportunity to give the process of technological integration a natural order, the ability to manage the production, economic and research activities of enterprises effectively.

As a prospect, the implementation of the stated scientific ideas must necessarily combine the functional areas of industrial enterprises: production and technological process, economics and research work (Nica, 2018).

\section{Results of research}

\section{Analytical assessment of technological} integration.

The Russian oil industry includes oil production, refining, transportation, sales of oil and petroleum products. At the primary stage there are involved 1,500 oil fields, about 800 of which are under development.According to the Ministry of Energy of the Russian Federation in 2017 oil refining and gas condensate on the territory of the country and the industrial production of commodity petroleum products from all types of crude oil was carried out by 80 special oil refining and gas processing companies, including:

- 28 large oil and gas refineries (with a capacity of 1 million tons of oil per year; with a total capacity of about 300 million tons of oil per year, or $86.3 \%$ of the total Russian capacity), members of vertically integrated oil companies;

- 9 oil refineries, not included in the structure of vertically integrated oil companies, or controlled by two or more shareholders, i.e. "independent refineries" (primary processing capacity of 33.8 million tons per year, or $10.8 \%$ of the total Russian capacity);

- 34 mini-refineries, including enterprises owned by vertically integrated oil companies (primary oil refining capacity of about 9.0 million tons of oil per year, or $2.9 \%$ of the total Russian capacity).

The modern structure of the oil industry is dominated by large vertically integrated oil companies. The most powerful of them are such oil and gas corporations as PJSC "Gazprom", PJSC "LUKOIL", JSC "NK "Rosneft", OJSC "Surgutneftegas", PJSC "Tatneft", JSC "ANK "Bashneft" (since October 2016 PJSC "NC "Rosneft" controls 50,0755\% of the shares), PJSC "NOVATEK", OJSC "Sakhalin Energy Investment Company Ltd." (JV), JSC "NKG Slavneft" (JV), JSC NK "RussNeft". Oil refining is represented by large enterprises: PJSC "Gazprom Neft", OJSC "TAIF NK", JSC "Forteinvest" (the part of JSC "Orsknefteorgsintez"), JSC "Antipinsky oil refinery", LLC "Neftegazindustriya" (it includes OOO "Afipsky refinery"), JSC "Neftekhimservis" (it includes LLC "Yaya refinery"), JSC "Novoshakhtinsk factory of oil products", etc. Transportation of oil and oil products is carried out mainly by enterprises of the joint stock company PJSC "Transneft".

The volume and depth of the hydrocarbon raw materials processing in the period $2005-2017$ had the dynamics of growth (figure 1). The depth of processing continues to grow; the volume of processing is reduced for objective reasons of the state of the oil market. The peak value of the commissioning of new and reconstructed oil refining plants fell on the pre-crisis for the industry in 2012 - 19 plants. 


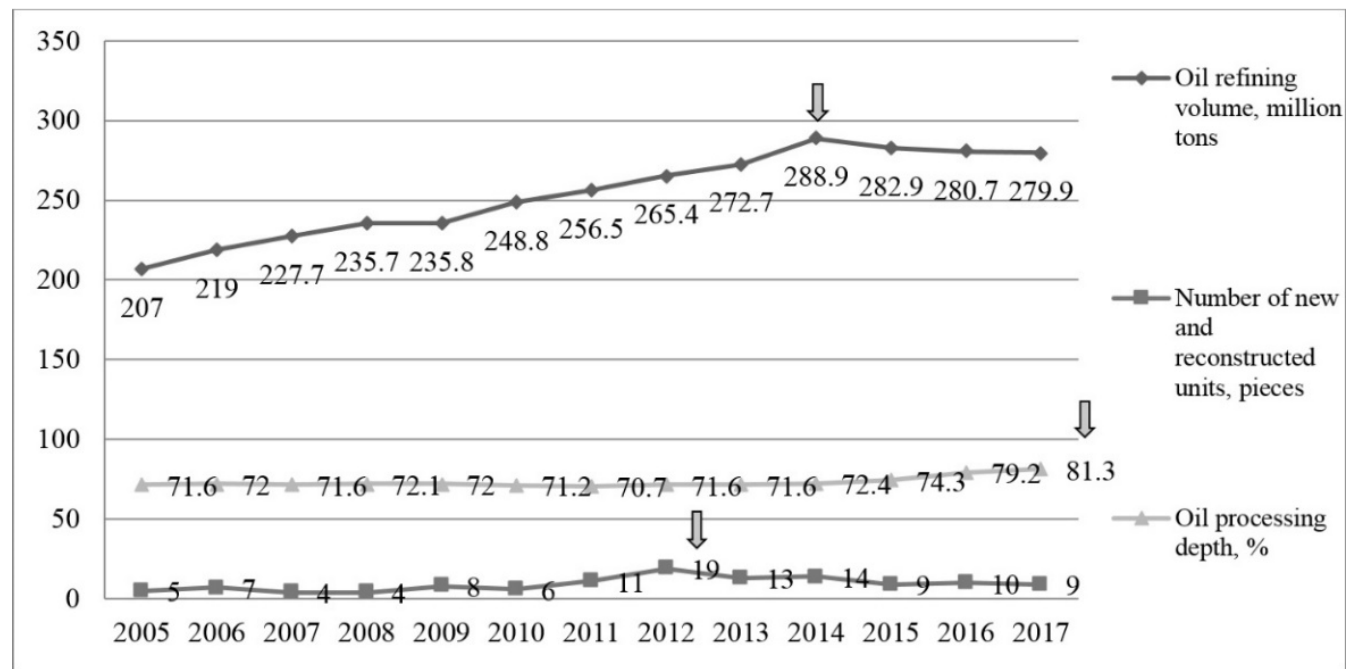

Figure 1 Dynamics of development of oil refining industry of the Russian Federation for 2005-2017 Source: Official website of the Ministry of Energy of the Russian Federation, 2019.

In 2015, instead of updating 27 installations, only 9 installations were retrofitted (figure 2). The main reason for the failure of the timing of implementation is the lack of planned supply of technology and equipment from Western contractors. Mobilization on internal sources of technological integration allowed increasing the depth of oil refining to $81.3 \%$ in 2017 . This contributed to a painless transition to the use of motor fuel only of the highest environmental class in Russia.
The main factor of long-term technological development is the inflow of capital investments. Statistics show that the manufacturing industry is directly dependent on the current economic conditions due to the consequences of the global crisis and sanctions restrictions on the supply of equipment and technologies, including dual-use products, and therefore, these industries are experiencing negative dynamics of investment in fixed assets.

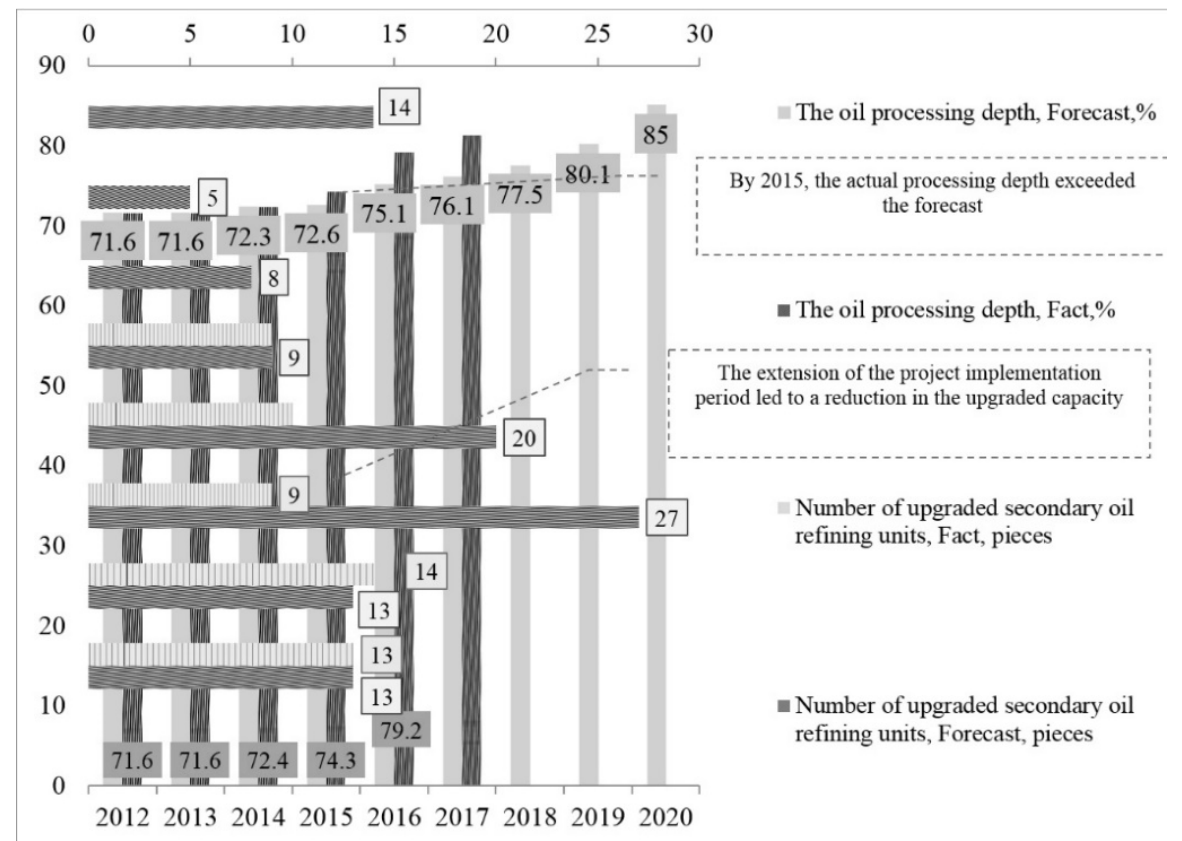

Figure 2 Comparison of forecast and actual indicators of development of oil refining industry of the Russian Federation for 2005-2015

Source: The Ministry of Economic Development of Russia, 2014. 
In the period of $2016-2017$ the situation stabilized, but this required the introduction of strict economy and cost optimization, including the development of new technologies (figure 3).

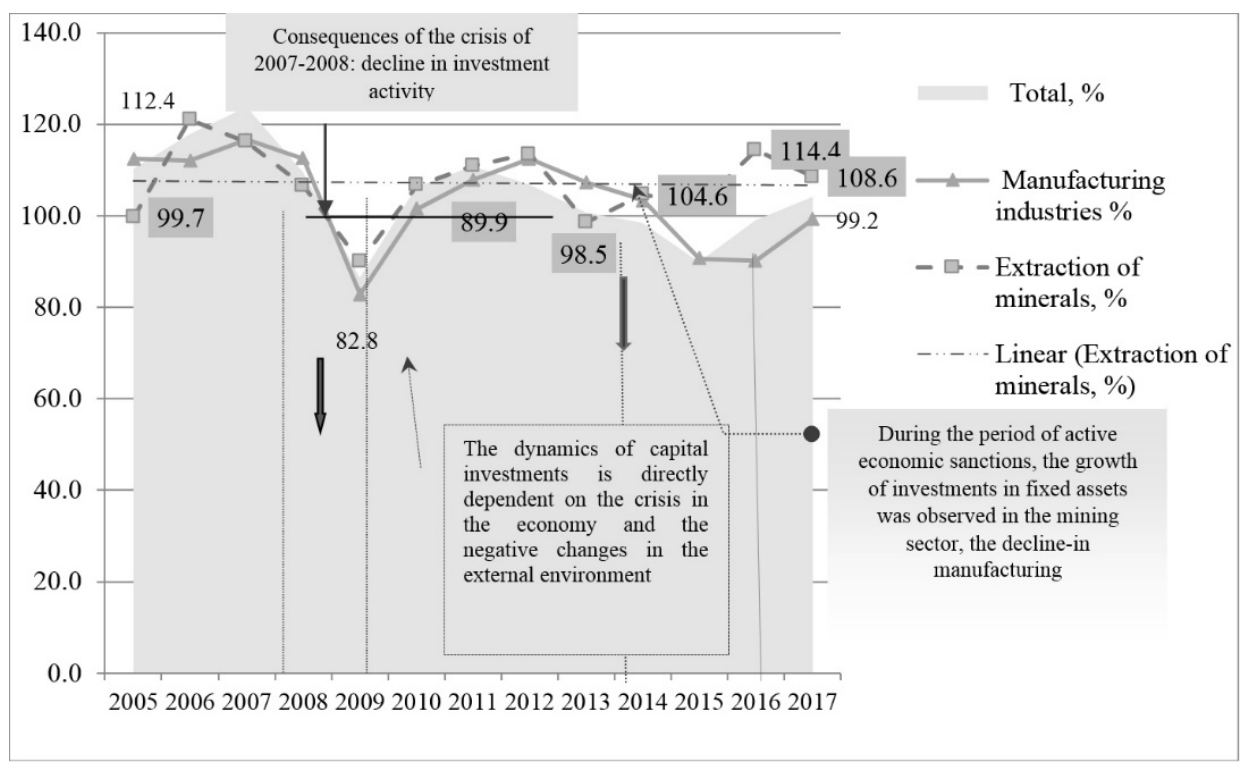

Figure 3 Dynamics of investments in fixed capital (in comparable prices) in the Russian Federation for the period 2005-2017, as a percentage of the previous period Source: The Federal state statistics service of the Russian Federation, n.d.

Financial support for technological integration is supported by companies and the state in the framework of special programs. There is a gradual overcoming of the existing deformation of technical and technological equipment of production by increasing capital investments in the development of the vertical chain. The share of capital investments in the reconstruction and modernization of production facilities decreased after 2012, while the volume of long -term financing of chemical production increased significantly; so in the period 2005-2017 industry investments in the reconstruction and modernization of chemical production exceeded the same figure for the country (figure 4). 


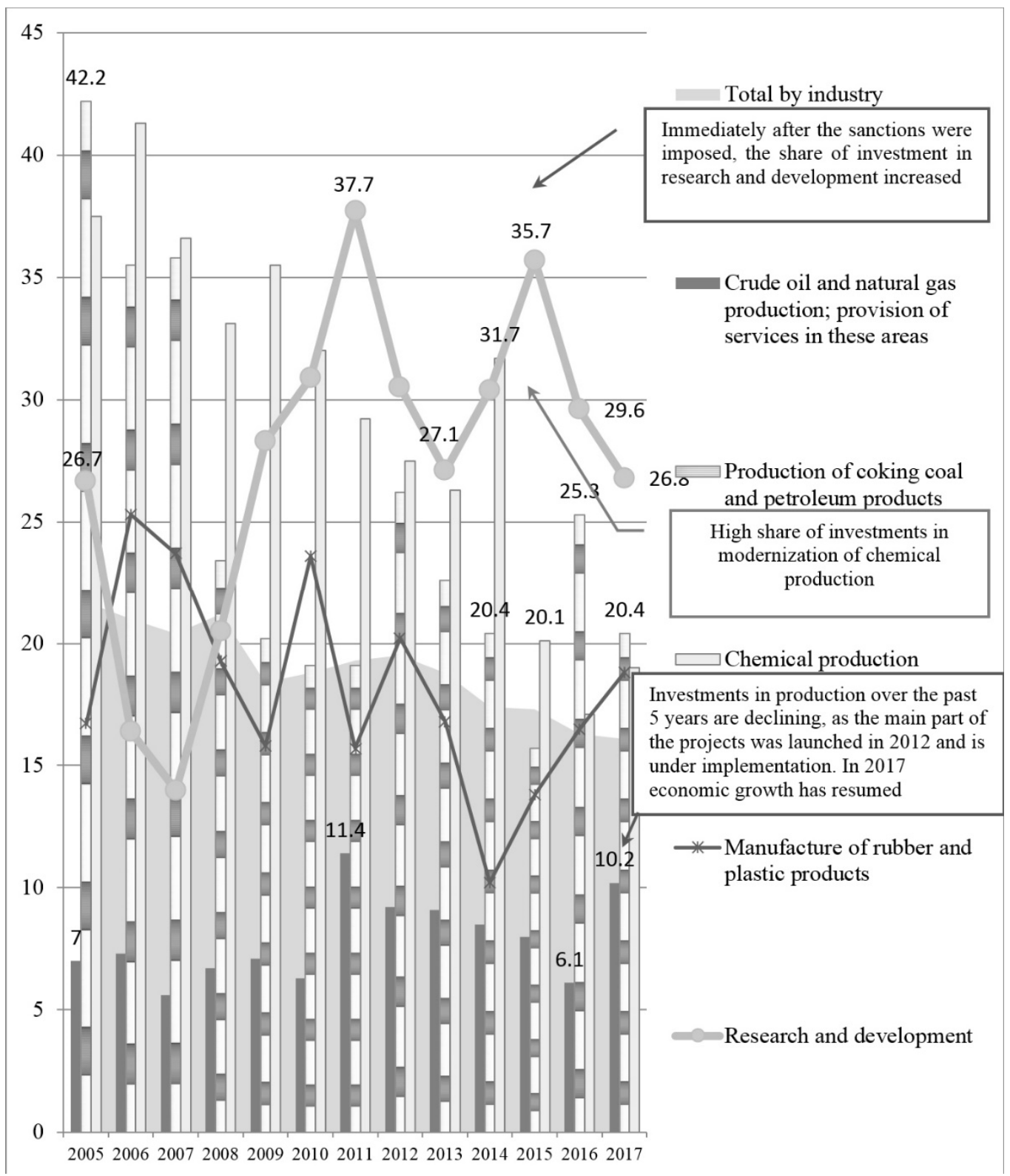

Figure 4 Share of investments aimed at reconstruction and modernization in 2005-2017, $\%$ of total investment in fixed assets in the Russian Federation Source: The Federal state statistics service of the Russian Federation, n. d.

The increased growth of capital investments during the period of active deployment of sanctions in 2013-2014 suggests that the state and enterprises directed funds to the implementation of the strategy of diversification and deepening of petrochemical production. Positive dynamics of investments in research and development indicate the growing activity of Russian research centers and laboratories. Until 2014, the share of advanced technologies used in Russian industries was insignificant, ranging from 3 to 5\%. In 2015, there was a sharp jump: due to the implementation of investment projects with the involvement of internal reserves of companies and targeted public funding, the number of technologies used in production increased tenfold.

If we analyze the dependence of import on the supply of technology, it can be noted that this trend continues, because the process of developing and commercializing of own scientific and practical developments is long and expensive. According to official data in 2015, in general, import of technologies prevailed over export in the fuel and energy sectors (figure 5). 


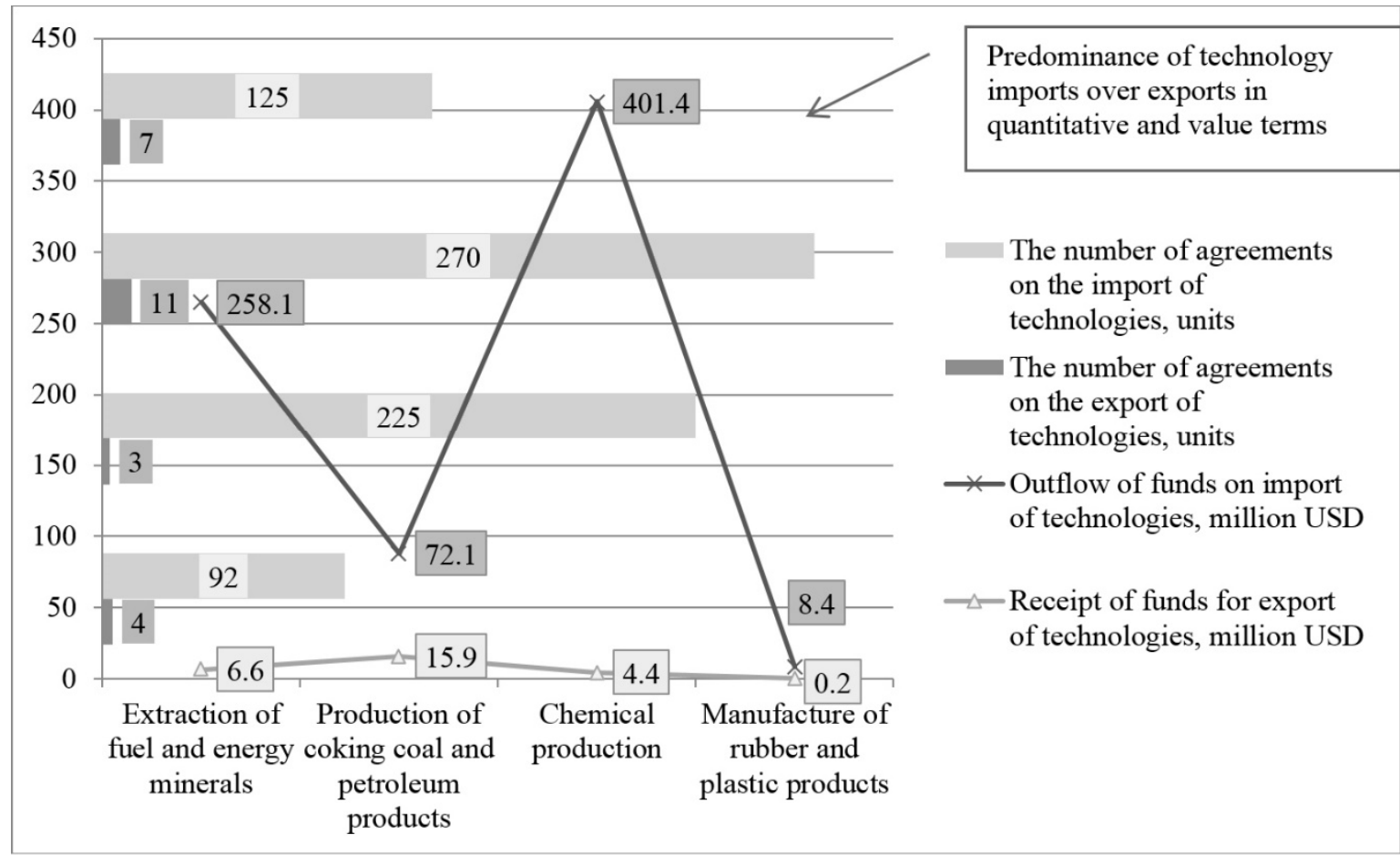

Figure 5 Ratio of export and import of technologies by branches of the fuel and energy complex of the Russian Federation in 2015

Source: Industrial production in Russia: statistical compendium, 2016.

Despite the positive dynamics of some indicators, the development of the domestic manufacturing industry is not yet consistent with the indicators of high technology. In order to achieve sustainable development in line with international standards and advanced achievements in science, Russian researchers must mobilize available resources to increase the innovative potential of all sectors of the manufacturing industry.

\section{Conclusion}

The study of the problems of technological integration in the manufacturing industry leads to the conclusion that from the point of view of scientific significance, the study conducted in the article will expand the existing approaches to the consideration of technological integration in enterprises of various sectors of the economy, will supplement the theory of organization with methodological provisions that reveal the essence and content of the conditions and factors of the dynamic process of technological integration. The obtained results allow giving a scientific substantiation of the methodology for the formation of the strategy of scientific and technological development of economic entities of various industries, taking into account the reflection and mitigation of external and internal technological challenges.

From the point of view of practical use of the obtained results, it is necessary to identify the development of a methodological approach to assessing the effectiveness of technological integration of manufacturing enterprises. This approach makes it possible to identify global trends and future challenges in the field of science and innovation, taking into account critical technologies and technological road routes for industrial enterprises, research centers and government agencies.

\section{Acknowledgments}

The reported study was funded by RFBR according to the research project № 19-01000081.sm

\section{References}

Druzhinin, A. G.\& Dong, Y. (2018).One Belt - One Road Initiative: A Window of Opportunity for Russia's

Western Border Regions // Baltic Region,10 (2), 39 55.

https://doi.org/10.5922/2079-8555-2018-2-3 . 
Gerasina, Yu. (2016). The impact of global transformation on function and dysfunction of management of economic reproduction process. Economic system, 1, 7-10.

https://elibrary.ru/download/elibrary 266888882246503 $\underline{5 . p d f}$

Grossman, T. (2018). The Rise of an Automated Jobless Society: Do Cutting-Edge Technologies Expel Workers Swifter than the Economy Can Identify New Jobs for Them?,Psychosociological Issues in Human Resource Management, 6(2), 62-

67.https://doi.org/10.22381/PIHRM6220185

Hardingham, Eileen, Vrbka,Jaromír,Kliestik,Tomas \&Kliestikova, Jana (2018). Will Cognitive Technology-Driven Automation Lead to Economic Growth? Journal of Self-Governance and Management Economics, 6(4),13-18.

https://doi.org/10.22381/JSME6420182

Industrial production in Russia: statistical compendium. (2016). Moscow: Rosstat.

Kovacs, O. (2018) The dark Corners of Industry 4.0 Grounding Economic Governance 2.0 // Technology in Society, 55, 140-145.

https://doi.org/10.1016/j.techsoc.2018.07.009 .

Mitea, Dana Raluca Elena (2018). The Expansion of Digitally Mediated Labor: Platform-Based Economy, Technology-Driven Shifts in Employment, and the Novel Modes of Service Work, Journal of SelfGovernance and Management Economics, 6(4),713.

https://doi.org/10.22381/JSME6420181

Neary, Breda, Horák,Jakub,Kovacova,Maria\&Valaskova, Katarina (2018). The Future of Work: Disruptive Business Practices, Technology-Driven Economic Growth, and Computer-Induced Job Displacement, Journal of Self-Governance and Management Economics, 6(4), 19-24.

https://doi.org/10.22381/JSME6420183

Nica, Elvira (2018). Will Robots Take the Jobs of Human Workers? Disruptive Technologies that May Bring About Jobless Growth and Enduring Mass Unemployment, Psychosociological Issues in Human Resource Management, 6(2), 56-61.

https://doi.org/10.22381/PIHRM6220184

Official website of the Ministry of Energy of the Russian Federation. Retrieved March 16, 2019.

https://minenergo.gov.ru/node/1212.

Oughton, E.J., Frias Z., Dohler M., Whalley J., Sicker D., Hall J.W., Crowcroft J., Cleevely D. D., Sicker Douglas, Hall Jim W., Crowcroft Jon, \&Cleevely D. D. (2018). The strategic national infrastructure assessment of digital communications // Digital Policy Regulation and Governance, 20 (3), 197-210.

https://doi.org/10.1108/DPRG-02-2018-0004 .

Popescu, Gheorghe H., Petrescu, Irina Elena,Sabie,Oana Matilda, \&Mușat, Mihaela (2018). Labor-Displacing Technological Change and Worldwide Economic Insecurity: How Automation and the Creation of Innovative Tasks Shape Inequality, Psychosociological Issues in Human Resource Management, 6(2), 80-85.

https://doi.org/10.22381/PIHRM6220188
Proskuryakova, L. (2017). Energy technology foresight in emerging economies. Technological Forecasting and Social Change, 119, 205 - 210. https://doi.org/10.1016/j.techfore.2016.05.024

The Federal state statistics service of the Russian Federation. Investments in non-financial assets. Dynamics of investments in fixed assets (in comparable prices) in the Russian Federation / Internet resource of the Federal state statistics service of the Russian Federation. Retrieved March 16, 2019.

http://www.gks.ru/wps/wcm/connect/rosstat main/rosstat /ru/statistics/enterprise/investment/nonfinancial/\#.

The Federal state statistics service of the Russian Federation (n. d.). Technological development of sectors of the economy. Share of investments aimed at reconstruction and modernization in the total volume of investments in fixed assets by types of economic activity in the Russian Federation Retrieved March 16, 2019.

http://www.gks.ru/wps/wcm/connect/rosstat main/rosstat /ru/statistics/economydevelopment/\#.

The Ministry of Economic Development of Russia (2014, April 5) About the approval of the State program of the Russian Federation "Energy Efficiency and Development of Power": approved by the Order of the Government of the Russian Federation No. 321 (with changes and additions). Access from the Portal of state programs of the RF. Retrieved March 16, 2019.

http://programs.gov.ru/Portal/programs/passport/32 .

Vishnevskiy, K., Karasev, O., Meissner, D., Razheva, A., \&Klubova, M. (2017). Technology foresight in asset intensive industries: the case of Russian shipbuilding. Technological Forecasting and Social Change. 119.

https://doi.org/10.1016/j.techfore.2016.05.001

Vochozka, Marek, Kliestik, Tomas,Kliestikova, Jana \& Sion, Grațiela (2018). Participating in a Highly Automated Society: How Artificial Intelligence Disrupts the Job Market, Economics, Management, and Financial Markets, 13(4), 57-62.

https://doi.org/10.22381/EMFM13420185

Wu, J., Harrigan, K. R., Ang, S. H., \& Wu, Z. (2019). The impact of imitation strategy and $R \& D$ resources on incremental and radical innovation: evidence from Chinese manufacturing firms // The Journal of Techology Transfer, 44 (1), 210-230.

https://doi.org/10.1007/s10961-017-9621-9.

Yao, Z., \& Zhou, W. (2015). Vertical or Horizontal: Endogenous Merger Waves in Vertically Related Industries. Journal of Economic Analysis \& Policy, 15 (3), 1237.

http://dx.doi.org/10.1515/bejeap-2014-0165 


\section{\Correspondence}

Alexander Miller

DostoevskyOmsk State University

Prospekt Mira 55A., 644077, Omsk, Russia

E-mail: aem55@yandex.ru 